\title{
MILTON'S REACTION TO HIS BLINDNESS ${ }^{1}$
}

\author{
by

\section{HENRY WILSON}

MAN is born into trouble as the sparks fly upwards and we tend to believe that he makes easy adjustments when these disasters occur. This is doubtless true of many misfortunes. It is often complicated when severe physical handicaps such as deafness, loss of vision, loss of limbs and other catastrophes overcome us, either slowly or suddenly. ${ }^{2}$

That which follows is the result of a number of factors of which the person's age and the person's temperament and character are pre-eminent. Some features are often seen. (1) Optimism and denial of the trouble. (2) Anxiety, fussiness and self-pity, sometimes apparently stimulated by the doctor who issues edicts which worry the patient more. (3) Suspicion or envy of others not so affected. (4) The tendency to believe that the disaster is some punishment for past crimes. (5) A readjustment of the individual's values and aims. Much will also depend on the wisdom with which he is nursed and his convalescence conducted. Our hero was clear about this factor after he became totally without vision:

To this I ascribe the more tender assiduities of my friends and soothing attentions and kind visits and reverential observances. ${ }^{3}$

Milton's mother suffered from serious visual defect before her early death. Milton began having difficulties with his sight when he was only thirty-six. Eight years later he was completely blind. Let us consider in the light of what we know of the normal way of dealing with handicaps, how Milton dealt with his blindness.

What manner of man was he? He was a man of warm-hearted impetuosity. The critical remarks he made about Cambridge education in the 1620 's would hardly have been forgiven him had he not had a real warmth towards others. This probably holds true also of his continued employment by the Council of State after he became blind. He was a man of energy, both bodily and mental. He was a man with a great belief in himself who seemed not at all dismayed at the ovation which he received in Italy. Little inner doubting creeps into the opinions which he voiced in his Tracts. Some of these qualities and the amazing belief in himself is expressed in the following passage in The Second Defence of the English People (1654):

When I was publicly solicited to write a reply to the Defence of the royal cause, when I had to contend with the pressure of sickness, and with the apprehension of soon losing the sight of my remaining eye, and when my medical attendants clearly announced, that if I did engage in the work, it would be irreparably lost, their premonitions caused no hesitation and inspired I 86 


\section{Milton's Reaction to his Blindness}

no dismay. I would not have listened to the voice even of Aesculapius himself from the shrine of Epidauris, in preference to the suggestion of the heavenly monitor within my breast: my resolution was unshaken, though the alternative was either the loss of my sight, or the desertion of my duty; 4

Did he criticise himself? Perhaps more than he admitted, but he combined a great belief in John Milton with a remarkable faith in others. He seemed to be blind about their obtuseness before he was blinded by his own visual defect. Others relied on him or felt that they could not do without him. This may also explain his continuing to be the Secretary for Foreign Tongues to the Council of State so long. He was argumentative and combatative. He was ready to score from others. He was not as frank as we feel he ought to have been in acknowledging that it was de Moulin and not More who wrote Regii Sanguinis Clamor. Yet he was a man who believed in self-discipline and continually expected it from others.

What does the prose tell us of the way in which Milton reacted to his severe handicap? The Preface to The First Defence (written, presumably, when he had finished the main body of the work) contains this passage:

If it be asked why we did not then attack him sooner? Why we suffered him to triumph so long, and pride himself in our silence? For others I am not to answer: for myself I can boldly say, that I had neither words or arguments long to seek for the defence of so good a cause, if I had enjoyed such a measure of health, as would have endured the fatigue of writing. And being but weak in body, I am forced to write by piecemeal, and break off almost every hour, though the subject be such as requires an unintermitted study and intenseness of mind. ${ }^{5}$

The whole period from the publication of Salmasius' Tract in 1649 until $165 \mathrm{I}$ seems to have been occupied in poor Milton searching furiously for quotations to rebut his opponent. The longest of his prose works is a pathetic commentary on Milton's over-activity and limited judgment in those fateful years. May he not have been referring to his own lack of wisdom in listening to medical advice when he says in Samson:

$$
\begin{aligned}
& \text { Had been fulfill'd but through mine own default, } \\
& \text { Whom have I to complain of but my self }
\end{aligned}
$$

By the time The Second Defence was published he had been totally blind for two years. Instead of the striving, restless Milton of The First Defence, he had found some peace. His own experiences had been 'perfected by feebleness and irradiated by obscurity'.7 The qualities of his English heroes, Fairfax and Cromwell outweigh the perverseness of his foreign detractors.

Let me then be the most feeble creature alive so long as that feebleness serves to invigorate the energies of my rational and immortal spirit: as long as in that obscurity in which I am enveloped, the light of the Divine Presence more clearly shines, then, in proportion as I am weak, I shall be invincibly strong: and in proportion as I am blind, I shall more clearly see. ... ${ }^{8}$

But he was still a Milton with an exaggerated opinion of himself. For instance:

I can hardly refrain from assuming a more lofty and swelling tone than the simplicity of an exordium may seem to justify: and much as I may be surpassed in the powers of eloquence and 


\section{Henry Wilson}

copiousness of diction, by the illustrious orators of antiquity, yet the subject of which I treat was never surpassed in any age, in dignity, or in interest. It has excited such general and such ardent expectation, that I imagine myself not in the forum or on the rostra, surrounded only by the people of Athens or of Rome, but about to address in this, as I did in my former Defence, the whole collective body of people, cities, states, and councils of the wise and eminent, through the wide expanse of anxious and listening Europe. I seem to survey, as from a towering height, the far extended tracts of sea and land, and innumerable crowds of spectators, betraying in their looks the liveliest interest, and sensations the most congenial with my own. ${ }^{\circ}$

He faced and rejected the charge that his blindness was some divine punishment for earlier peccadilloes:

And with respect to myself, though $I$ have accurately examined my conduct, and scrutinized my soul, I call thee, $O$ God, the searcher of hearts, to witness, that I am not conscious, either in the more early or in the later periods of my life, of having committed any enormity, which might deservedly have marked me out as a fit object for such a calamitous visitation. ${ }^{10}$

And about the same time as The Second Defence was published he wrote to Oldenberg:

If my health, and the deprivation of my sight which is more grievous than all the infirmities of age, or the cries of these impostors, will permit, I shall readily be led to engage in other undertakings, though I do not know whether that can be more noble, or more useful: for what can be more noble, or more useful, than to vindicate the liberty of man. An inactive indolence was never my delight: but this unexpected contest with the enemies of liberty has involuntarily withdrawn my attention from very different and more pleasurable pursuits. ${ }^{11}$

I can only find two evidences of self-pity, the first is the passage in the Preface to The First Defence already noted. The second is in the Defensio pro Se quoted by Tillyard:

But this was the time of my worst distresses, when divers troubles combined to oppress me: bad health, the grief of two deaths at home, and the now utter failure of my eye-sight. ${ }^{12}$

What does his poetry tell us of his reactions to his blindness? The number of direct references to it are few enough. The 'Sonnet on his Blindness' underlines the difference between the 'patience to prevent that murmur' and the 'thousands who post o'er Land and Ocean'. There is the autobiography in the second 'Sonnet to Skinner':

$$
\text { ... nor bate a jot }
$$

Of heart or hope; but still bear vp and steer

Right onward. What supports me, dost thou ask?

The conscience, Friend, to have lost them overply'd

In libertyes defence, my noble task,

Of which all Europe talks from side to side.

There is the best known passage in the Invocation to Light in Paradise Lost, Book III, where he would equal in renown Homer and the Prophets old, but he accepts the inevitable in the final prayer that the celestial light will irradiate his inmost thoughts. Thus the proud Milton still toyed with greatness when he became blind as he had during early life expected fame. But that he really 


\section{Milton's Reaction to his Blindness}

believed that he would regain his sight, the letter to Philaras (1658) gives no support:

... And though your physician may kindle a small ray of hope, yet I make up my mind to the malady as quite incurable. ${ }^{13}$

however much the busybody Manoa thought the Almighty would relieve Samson's sight:

But God who caus'd a fountain at thy prayer

From the dry ground to spring, thy thirst to allay

After the brunt of battel, can as easie

Cause light again within thy eies to spring,

Wherewith to serve him better then thou hast: ${ }^{14}$

He was not explicitly envious.

He did not blame himself. There are but the two evidences of self-pity. That his blindness caused an agonising reappraisal is clear from the two sonnets and the Invocation to Light.

At the time this agonising reappraisal was needed, (1654) Milton returns to poetry and in it he records the disappointment, the despair, the revenge of the devils in the early books of Paradise Lost. In theory, because of Milton's great opinion of himself he would not easily suffer a blow like loss of sight. The reality of these baser motives in the fallen angels surely derived something very personal from Milton's experience? Consider Book II, Paradise Lost, and Moloch's impetuosity to do anything impulsive rather than to be patient. This has the ring of the disappointed husband, rushing into a tract upon Divorce. Belial's solution was a more despairing and depressing one which appealed little to the poet. Mammon shows something of a worthier character than his two companions:

... but rather seek

Our own good from our selves, and from our own

Live to our selves, though in this vast recess,

Free, and to none accountable, preferring

Hard liberty before the easie yoke

Of servile Pomp. Our greatness will appear

Then more conspicuous, when great things of small,

Useful of hurtful, prosperous of adverse

We can create, and in what place so e're

Thrive under evil, and work ease out of pain

Through labour and endurance. ${ }^{15}$

And when he proposes:

... This Desart soile

Wants not her hidden lustre, Gemms and Gold;

Nor want we skill or art, from whence to raise

Magnificence; and what can Heav'n shew more ${ }^{16}$

he forecasts the solution that Adam comes to after his melancholy, a solution which it is not difficult to imagine Milton came again and again to experience 


\title{
Henry Wilson
}

in those periods of gloom which, I suggest, a man of his calibre could not have avoided. However much the 'great consult' owed to the parliamentary debates which Milton heard, it depends as much upon Milton's inner experience and battle.

Let us compare this with Eve's reaction after the debauch. Neither she nor the devils really blame themselves. She weeps many tears. She is amazed when she is accused by the Son, but her sorrow is because she expects early death and because Adam is so manifestly sunk in the deepest gloom. Finally she makes her proposals for sterility and self-destruction. These have many modern counterparts in the clinician's experience. Eve is tempted to refuse the adventure of life which the Almighty's lenience after her own wickedness has set before her. If Milton had similar temptations, by contending with them, his poetry could express a new-found serenity. It is the slower-witted Adam who sees through the arguments of his consort as clearly as he had failed to see through her temptation in the previous book:

\author{
No more be mention'd then of violence \\ Against our selves, and wilful barrenness, \\ That cuts us off from hope, and savours onely \\ Rancor and pride, impatience and despite, \\ Reluctance against God and his just yoke \\ Laid on our Necks. ${ }^{17}$
}

In this whole parallel between the pride, envy and revenge motive in the devils and the pride and envy and then revenge motive in Eve, Milton was living out the conflict that had been constantly in his mind since the onset of visual troubles in 1644 and without which he could not have swum into the peace, with which he ends the Invocation to Light, or the solution which comes after the crisis in Book X of Paradise Lost. One may study the prose and conclude that anger about his limitations played no part in his Olympian thoughts. One may begin to doubt this conclusion when one reads the sonnet on his blindness. Is one justified in believing that revenge certainly, and envy probably, were woven into the angelic and human characters of Paradise Lost and derived nothing from the intensity of these sentiments in Milton's mind? The question is not so much 'had he not been totally blind would Paradise Lost ever have been written'? but 'had he not been blind could such a human Paradise Lost ever have emerged?'

Let us now consider Adam and Samson. It has been recognized that the blind Samson is derived from some of the feelings of the blind Milton. When we compare Adam's soliloquy (Book X 1. 720,) with the first seven hundred lines of Samson, in both cases we are studying a disturbance of mind behind which lies long thought, vivid and continuing experience. Both believe that they were divinely chosen:

$\ldots$ is this the end

Of this new glorious World, and mee so late

The Glory of that Glory, ${ }^{18}$ 


\section{Milton's Reaction to his Blindness}

Why was my breeding order'd and prescrib'd

As of a person separate to God,

Design'd for great exploits: ${ }^{19}$

Both ruminated on their living death and the fact that their woes might go on * beyond man's mortal span. Both believed in the propagated curse. Samson lost his sleep:

The anguish of my Soul, that suffers not

Mine eie to harbour sleep, or thoughts to rest. ${ }^{20}$

and it is implied that Adam did so too. ${ }^{21}$ Both are lengthened out in their despair ${ }^{22}$ and both heroes are convinced that they themselves are to blame:

ADAM: $\quad \ldots$ Him after all Disputes

Forc't I absolve: all my evasions vain

And reasonings, though through Mazes, leads me still

But to my own conviction: first and last

On mee, mee onely, as the sourse and spring

Of all corruption, all the blame lights due: ${ }^{23}$

SAMSON: Appoint not heavenly disposition, Father,

Nothing of all these evils hath befall'n me

But justly: I my self have brought them on,

Sole Author I, sole cause:24

Indeed in Samson's case it is implied that he could justifiably blame Dalila or the delays of the other Jewish states. How different is this from the absence of self-blame in Milton's prose. For Samson (11. 6o6-32) only the description of the most hideous physical symptoms can describe his mental sufferings. Strikingly there is no revenge in Adam or in Samson. It is worthy of emphasis that the Chorus grieved as it is by his bondage and lost sight, is more worried still by his mental imprisonment:

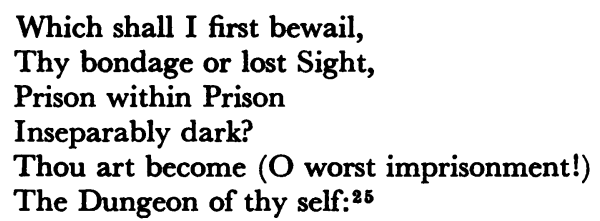

Samson pleads for death. ${ }^{26}$ Today he would have been regarded as a potential suicide. Adam hardly less so. The conclusion of both illnesses is interesting. In Adam's case, it follows the insight which Eve's proposals for sterility

So Death shall be deceav'd his glut, and with us two

Be forc'd to satisfie his Rav'nous Maw. ${ }^{27}$

prompts. For the passage already cited ('No more be mention'd then of violence') shows Adam gaining insight. And Samson, having dealt in a puritanically haughty way with Harapha and the Officers begins to feel some 


\section{Henry Wilson}

rousing motions in himself. The internal and external promptings might escape the visiting clinician; Milton from his own experiences describes the stimulus to effective action.

The doctor familiar with mental disturbances is convinced of the reality of Adam's and of Samson's disorders. They ring true to what he frequently meets in melancholic depression. This is a state where the sufferer is 'off colour', slowed-up in thought and action, and the internal bodily functions are disturbed, sleep and appetite and weight are lost. $\mathrm{He}$ is profoundly miserable, he is convinced he has sinned greatly or he is being penalised for youthful errors. He may contemplate death with pleasure, pray for it, seek it by his own hand.

Was Milton describing what he had seen in others? Was he giving a précis of Robert Burton's profound description, published thirty years before Milton lost all sight. Both possibilities are unlikely. Milton was very learned, he was not profoundly imaginative. Shakespeare, whose range of thought and fancy so out-topped Milton's, never described melancholia with the clarity that our poet achieved.28

We must remember that Burton specifically distinguished between melancholy of disposition and of habit. What Burton calls melancholy of disposition he thus describes:

In disposition, is that transitory Melancholy which goe sand comes upon every small occasion of sorrow, need, sickness, trouble, fear, grief, passion, or purturbation of the mind, any manner of care, discontent, or thought, which causeth anguish, dulness, heaviness and vexation of spirit, any ways opposite to pleasure, mirth, joy, delight, causing frowardness in us, or a dislike. In which equivocal and improper sense, we call him melancholy, that is dull, sad, sour, lumpish, ill-disposed, solitary, any way moved, or displeased. And from these melancholy dispositions no man living is free, no Stoick, none so wise, none so happy, none so patient, so generous, so godly, so divine, that can vindicate himself; so well-composed, but more or less, some time or other, he feels the smart of it.s0

But all these melancholy fits, howsoever pleasing at first, or displeasing, violent and tyrannizing over those whom they seize on for the time; yet these fits I say, or men affected, are but improperly so called, because they continue not, but come and go, as by same objects they are moved. 30

Now this is a remarkably close description of what is now called 'reactive depression': attacks of sorrow precipitated by outward events, large or small. The reaction is curiously variable and varying. It may quickly go when attention is paid to the sufferer, his frustrations removed, his demands satisfied. Its course is usually short; much will depend on the resilience of the patient. Whereas prolonged melancholia is attended by self-blame, in reactive depression the victim blames others, and that morbidly. He seeks to defeat those who have wronged him, or blame a Fate that pours not hail and brimstone over their heads. His arguments are often superficial, always selfish. He designs revenge rather than self-criticism. He may threaten suicide, and complains that because events have thrust frustration upon him he will refuse the role of parenthood. Indeed, Eve's proposals for suicide or sterility bear a modern air. Such choices 


\section{Milton's Reaction to his Blindness}

were made before 1939, some still justify them or seek to live by them in a Welfare State.

Both the Devils and Eve are overwhelmed by a realization that none of them can have their own way. Life even in Heaven or in Paradise may be threatened: a profound belief in themselves or in their rights is no shield against adversity. If we compare the Devils' idea of supremacy with the ideas Milton expressed about himself before 1651 , are they very different in quality? The anger and frustration that a man of Milton's character and ambition can have been expected to feel when he lost 'that one talent' is what is expressed by the Devils and by Eve. Their situation provided just the circumstances in which they would feel what Milton felt about his blindness, even though he purged his prose of any such 'murmur'.

Have we not here some clue as to why after 1654 he returned to poetry? And can we not also with some certainty aver that the reason why he wrote so little for two years after Tetrachordon and Colasterion ( 1646 ) was not alone a disappointment in his countryman, or the disturbances of the noisy Powell tribe. ${ }^{31}$ May it not have been Milton's first attack of melancholic habit lasting, as in Burton's description, 'a settled humour ... not errant, but fixed'. ${ }^{32}$

In the modern reactive depressions, events precipitate them, they may not be brief-lived: they may pass imperceptibly into the prolonged 'habit'. The disturbances which his unlucky marriage made, or the Powells caused would have been a reactive depression to begin with but could pass into the Samsonlike 'habit'. We shall never know; there is nothing inherently improbable in such a sequel. ${ }^{33}$

Two other points. When Phillips ${ }^{34}$ states that Milton did no work between the autumn and vernal equinox there is a possible clinical explanation of this. In a few cases a melancholic's 'habit' is annual, six months depression, six months freedom. It is in the summer that the symptoms tend to be worse, but this is not invariable. Therefore, Phillips may have recorded an important medical observation.

It has been assumed that Milton's mood changes were all depressive. But the sufferers from Burton's continuate disease may have symptoms of the other extreme-frenzied restlessness, productive or the reverse. This might account for Milton's rapid wooing of Mary, it might explain the violence of the first edition of The Doctrine and Discipline of Divorce, the passing of this phase would explain the more temperate tone of the second edition. No attempt must be made to equate Milton's energy with madness. But a true assessment of his life must neither neglect the possibility of his mental illnesses, nor prevent the historical imagination playing around the fact that what Milton says about his blindness in his prose is not the whole story of his reactions.

If these problems are ever solved men will still feel that Milton was a proud man, and an obtuse man. They should draw comfort from the resilience of a haughty poet who was not defeated by his blindness but suppressed his human disappointment from his prose, only to sublimate it in his poetry. 
I. Some of my indebtedness to Dr. E. M. W. Tillyard is, I hope, apparent. I can claim only to have read some of the literature about Milton, but the demands of medical practice must excuse that.

2. Some of the most interesting reactions to adversity are those which are seen in persons who are gradually overtaken by serious cerebral disease and unconsciously withdraw their circle of interests, arrange their possessions most carefully and seem to be acting so that others shall not detect the gradual failure of their powers. See Margaret Reinhold, 7. ment. Sci., 1953, c1x, 130.

3. BонN, Milton's Prose Works, 1, 239.

4. ВонN, $1,238$.

5. ВонN, $1,6$.

6. Samson Agonistes; $1,44^{-6}$.

7. BOHN, I, 239.

8. Вони, I, 239.

9. BOHN, I, 219.

IO. BOHN, I, 237.

II. BонN, II, 505.

12. Quoted by Tillyard, Milton, p. 189 .

13. ВонN, m, 508 .

14. Samson Agonistes, 1, 581-5.

15. Paradise Lost, bk. In, 252.

16. Paradise Lost, bk. II, 270.

17. Paradise Lost, bk. $x, 104^{1-6 .}$

18. Paradise Lost, bk. $x, 720$.

19. Samson Agonistes, 30.

20. Samson Agonistes, 458-9.

21. Paradise Lost, bk. x, 846 .

22. Paradise Lost, bk. $x, 773$, and Samson Agonistes, $118-23$.

23. Paradise Lost, bk. $x, 828$.

24. Samson Agonistes, 373-9.

25. Samson Agonistes, $151-6$.

26. Samson Agonistes, 629, 649.

27. Paradise Lost, bk. $x, 990-1$.

28. Cleopatra and Brutus do not fulfil the requirements though they have melancholic episodes and commit suicide. The epithet 'the melancholy Jaques' describes his cynicism. Hamlet is far too complicated a character, as indeed is Lady Macbeth though she too (? in error) committed suicide. Timon seems to have the rashness of hypomanic largesse with the miserliness of settled melancholy, yet this is too summary a view. It may be objected that within the limits of a three-hour play, Shakespeare could not describe melancholia. But he brilliantly portrayed at least three other psychiatric conditions: one form of schizophrenia (Ophelia), the concentric diminution of a senile's mind (Lear), and the behaviour of a man wracked with guilty anxiety (Hotspur). See Lady Percy's protest to Hotspur, I Henry IV, II, iii.

29. Burton, R., Anatomy of Melancholy, Shilleto, p. 164.

30. Burton, R., ibid., p. 167.

31. Melancholic depression of the 'habit' or Samson-type may arise completely unexpected. The outward stimulus cannot be discovered, may not exist.

32. Since the 1930's melancholic attacks of the 'habit' sort have been far more amenable to successful treatment. Previously they were likely to last six months, often longer. Burton was obviously impressed by their tenacity, and saw many cases which never recovered. 


\section{Milton's Reaction to his Blindness}

But there is little doubt that he saw other long cases which did recover. And my assumption is that a similar long-standing 'continuate' disease affected Milton once in 1647 if not on later occasions too.

33. If Milton had a reactive depression following his blindness, and at other times serious personal troubles precipitated them, did he then have such trouble when Edward King was drowned? My answer would be 'No' for real as the grief was, it had not that quality of belonging which the loss of sight, or the melancholy habit produces. Milton in Lycidas conveys the sense of extra-personal rumination which Adam and Samson only regained when they recovered.

34. Hanford, Milton Handbook, p. 28. 